ANUARIO DE Estudios MEDIEVALES

48/1, enero-junio de 2018, pp. 391-418

ISSN 0066-5061

https://doi.org/10.3989/aem.2018.48.1.13

\title{
EL DESARROLLO DEL CULTO A SAN LORENZO EN HUESCA, SIGLOS XIII-XIV: UN ESTUDIO DE CASO DE LAS PRÁCTICAS DE RELIGIÓN CÍVICA EN LA CORONA DE ARAGÓN MEDIEVAL*
}

\author{
DEVELOPMENT OF THE CULT OF SAINT LAWRENCE IN HUESCA \\ $\left(13^{\text {th }}-14^{\text {th }}\right.$ CENTURIES): A CASE STUDY OF THE PRACTICES \\ OF CIVIC RELIGION IN THE MEDIEVAL CROWN OF ARAGON
}

\author{
MARÍA JESÚs GARCÍA ARNAL \\ Universidad de Zaragoza \\ https://orcid.org/0000-0002-7541-7383
}

\begin{abstract}
Resumen: En el transcurso del siglo XIII, los gobiernos urbanos de la Corona de Aragón mostraron una preocupación creciente por reforzar su recién adquirida autoridad. Una de las soluciones, aunque no la única, fue adoptar atributos religiosos que dotasen al conjunto de sus habitantes de un foco de identidad colectiva en un fenómeno que la historiografía ha denominado religión cívica. El objeto de este trabajo es analizar, a través de un estudio de caso, un aspecto concreto de esta dinámica: la incorporación de un santo patrón que representara a la ciudad y dotara de cohesión interna a una comunidad urbana diversa. En concreto, trataré de reconstruir el proceso de captación del santo Lorenzo por parte del concejo de la ciudad de Huesca y establecer una comparativa con procedimientos similares y coetáneos en otras ciudades de la Corona.
\end{abstract}

Palabras clave: religión cívica; identidad urbana; Corona de Aragón; santos patrones; Huesca; san Lorenzo; gobiernos urbanos.

Abstract: During the $13^{\text {th }}$ century, the urban governments of the Crown of Aragon took measures in order to strengthen their recently acquired authority, such as assuming religious attributes that would provide their inhabitants a focal point for collective identity. This is a phenomenon known as civic religion. The purpose of this paper is to analyse a specific aspect of this trend through a case-study: the incorporation of a patron saint that represented the city and provided internal cohesion to a diverse urban community. In particular, this paper seeks to recreate how the city council of Huesca chose Saint Lawrence as the city's patron saint. Subsequently, this process will be compared with similar contemporary processes in other cities of the Crown of Aragon.

Keywords: civic religion; urban identity; Crown of Aragon; patron saints; Huesca; Saint Lawrence; urban government.

\section{SUMARIO}

1. Introducción.- 2. El desarrollo del culto a san Lorenzo en la ciudad de Huesca (siglos XIII-XV). Un estudio de caso.- 3. Manifestaciones de religión cívica en la Corona de Aragón.- 4. Conclusiones.- 5. Bibliografía citada.

* Este trabajo se ha realizado gracias una beca del Gobierno de Aragón para la contratación de personal investigador del año 2015. Se integra en el Proyecto "Las transformaciones del Estado: estructuras políticas, agentes sociales y discursos de legitimación en el reino de Aragón (siglos XIV-XV). Una perspectiva comparada” (HAR2015-68209-P), así como en las del Grupo de Investigación CEMA. Asimismo, quiero expresar mi agradecimiento a los evaluadores por sus comentarios y apuntes que han contribuido a la mejora de este trabajo.

Cómo citar este artículo: García Arnal, María Jesús (2018), El desarrollo del culto a San Lorenzo en Huesca, siglos XII-XV: un estudio de caso de las prácticas de religión cívica en la Corona de Aragón medieval, "Anuario de Estudios Medievales" 48/1, pp. 391-418. https://doi.org/10.3989/aem.2018.48.1.12

Copyright: (C) 2018 CSIC. Este es un artículo de acceso abierto distribuido bajo los términos de la licencia de uso y distribución Creative Commons Reconocimiento 4.0 Internacional (CC BY 4.0). 


\section{INTRODUCCIÓN ${ }^{1}$}

A lo largo del Doscientos, en los territorios de la Corona de Aragón tiene lugar una progresiva institucionalización del poder local en las ciudades que coincide con una ampliación de los mercados y las redes comerciales, así como con la acumulación propiedades agrarias en manos de las elites terratenientes radicadas en ellas. Este proceso es consecuencia de una prolongada fase de expansión económica que conecta un significativo crecimiento demográfico con un desarrollo de las periferias agrícolas urbanas y un avance todavía poco conocido en las actividades manufactureras ${ }^{2}$. Por su parte, el auge urbano acompañó y potenció el incremento de las dimensiones de los aparatos de estado de la Corona al servicio de una monarquía cada vez más ambiciosa, que encontró en el Mediterráneo occidental un espacio político en el cual intervenir de forma decidida ${ }^{3}$. En las ciudades, la reorganización de las estructuras de gobierno fue la respuesta al incremento paulatino de la presión fiscal por parte de la monarquía en el curso de este periodo. En otras palabras, una fiscalidad más intensa llevó consigo una transformación manifestada, de manera principal pero no exclusiva, en la constitución de gobiernos municipales con una mayor participación de los llamados "ciudadanos" y que integraba un colectivo relativamente amplio de familias de los estratos superiores de la sociedad urbana.

Estas elites políticas intervendrán de forma visible en numerosas cuestiones relacionadas con la gestión del espacio físico y moral urbano a través de la financiación de infraestructuras, de la implementación de una caridad institucional, de la consecución de privilegios y dispensas fiscales y de la fijación de sistemas tributarios más o menos complejos ${ }^{4}$. Asimismo, van a manifestar su habilidad para manejar asuntos relacionados con lo religioso en su propio beneficio, supervisando o participando en la construcción de templos e interviniendo en rituales y ceremonias públicas de esta naturaleza. A través de este tipo de mecanismos, los gobiernos municipales persiguen legitimar una autoridad que, de manera informal, se remonta a la centuria anterior, pero que, en el terreno insti-

\footnotetext{
${ }^{1}$ Abreviaturas utilizadas: $\mathrm{ACH}=$ Archivo de la Catedral de Huesca; $\mathrm{AHB}=$ Arxiu Històric de Barcelona; AHN = Archivo Histórico Nacional; AHPH = Archivo Histórico Provincial de Huesca; AHPZ = Archivo Histórico Provincial de Zaragoza; APSLH = Archivo de la Parroquia de San Lorenzo Mártir de Huesca; ASV = Archivo Secreto Vaticano; BPH = Biblioteca Pública de Huesca.

${ }^{2}$ Sesma, Laliena 2009.

${ }^{3}$ Sánchez 1995.

${ }^{4}$ Bensch 1995; Iranzo 2004.
} 
tucional, cristaliza en este periodo ${ }^{f}$, a la vez que dotan de un sentido de identidad colectiva a una sociedad urbana en constante crecimiento por la vía de la inmigración y aquejada de una desigualdad económica y social cada vez mayor. En este contexto, con un creciente culto a la Virgen y los santos, no es extraño que estas figuras de carácter sacral capitalicen las dedicaciones de las iglesias de nueva fundación, la tutela de las instituciones de beneficencia y la devoción de las cofradías, o que acaben por convertirse en símbolos de la unidad del cuerpo social urbano ${ }^{6}$.

Este fenómeno ha sido catalogado por la historiografía dentro del más amplio concepto de "religión cívica", desde que André Vauchez en la década de 1980 difundiera el término para referirse a la apropiación de valores religiosos por parte de los poderes civiles ${ }^{7}$. Desde hace más de veinte años, numerosos estudios han mostrado el potencial de esta noción, especialmente en el ámbito italiano, donde ha sido ampliamente documentada ${ }^{8}$. Estos trabajos han explorado las distintas formas de las que se sirvieron los gobiernos urbanos a través de la organización y la participación en las fiestas religiosas -especialmente en lo que respecta a las procesiones y ceremonias relacionadas con la Virgen, el Corpus Christi o los santos patrones-, no solo con el objetivo de cohesionar una comunidad urbana heterogénea, sino también para reforzar su autoridad y autonomía ${ }^{9}$. No obstante, esta tendencia está lejos de ser exclusiva de esta región mediterránea y ha sido constatada de forma más o menos general en el resto de Europa ${ }^{10}$.

En lo que se refiere a la Península, esta problemática ha tenido una repercusión limitada en la historiografía de las ciudades medievales y, en particular, en la relativa a la Corona de Aragón ${ }^{11}$. A pesar de que existe una creciente bibliografía sobre la formación de identidades en la Edad Media en este espacio político ${ }^{12}$, la religión cívica y sus lazos con esta diná-

${ }^{5}$ Laliena 2010.

${ }^{6}$ García de Cortázar 2006.

${ }^{7}$ Vauchez 1986, 1987, 1995.

${ }^{8}$ Sin pretensión de exhaustividad, algunas de las obras que abordan estas cuestiones en el periodo son: Andenna 2011; Bertrand, Taddei 2008; Boesch, Michetti 2002; Boucheron, Chiffoleau 2000; Cannon, Wiliamson 2000; Crouzet-Pavan 2003; Golinelli 1991; Muir 1986; Terpstra 1995.

${ }^{9}$ Muir 1986, pp. 17, 83-85, señala cómo san Marcos se convirtió no sólo en un elemento principal de la identidad urbana veneciana, sino también un símbolo de la independencia y libertad de la ciudad frente al principado y el papado.

${ }^{10}$ En este sentido $c f$. los estudios de Brown 2011 sobre Gante; y de Harvey 2006 sobre Durham; además de la obra colectiva de Marinković, Vedriš 2010, que recoge diversos ejemplos de cultos urbanos, algunos en lugares tan remotos como Transilvania o Mazovia.

${ }^{11}$ Las obras de Fernández 2005; Pérez-Embid 2002 son de referencia para la Corona de Castilla.

${ }^{12}$ Sabaté 2014a, 2014b, 2015a, 2015b; Iradiel, et al. 2016. 
mica es un asunto que no ha recibido suficiente atención. La mayoría de los trabajos relacionados con los cultos urbanos en este periodo, con algunas excepciones, se alejan del estudio de las iniciativas de origen concejil $^{13}$. Por lo general, se trata de planteamientos de corte tradicional y carácter local, con frecuencia con marcadas connotaciones hagiográficas que tratan de rastrear, sin mucha voluntad crítica, las primeras menciones de los santos en las fuentes de cualquier naturaleza, normalmente con la intención de remontar la antigüedad del culto al patrón en una ciudad concreta lo máximo posible y con el ánimo de acreditar la intensidad de la devoción.

Mi contribución pretende ser un recordatorio de que estas cuestiones no pueden ser desdeñadas en el análisis de las dinámicas sociales y culturales de las ciudades de la Corona y, mediante un breve estudio de caso, mostrar el potencial que tiene en relación a una expresión característica de la religión cívica: la adopción de un santo patrón que represente a la ciudad y despliegue su protección sobre ella, junto con los rituales públicos relacionados con esta devoción. El objetivo central de este trabajo es intentar reconstruir el proceso de captación de la figura del santo Lorenzo por parte del gobierno urbano de Huesca frente a otros cultos vigentes en ese momento en la ciudad. Un proceso que arranca, según los indicios que poseemos, del primer cuarto del siglo XIII y culmina a principios del $\mathrm{XIV}$, con un éxito tan rotundo que no solo perdura secularmente, sino que alcanza hasta la actualidad. Seguidamente, voy a tratar de señalar que este fenómeno concreto de la incorporación de santos y santas a la religiosidad urbana por intercesión de los concejos como parte del afianzamiento de su autoridad, muestra una regularidad en los territorios peninsulares de la Corona de Aragón y guarda ciertas similitudes más allá del marco temporal. Para ello he elegido cuatro de las principales ciudades de la Corona -Barcelona, Tarragona, Zaragoza y Valencia- en las que he contrastado, de forma sucinta y a través de referencias bibliográficas, procesos similares al documentado para Huesca ${ }^{14}$.

\footnotetext{
${ }^{13}$ Sobre el papel de las fiestas cívicas en la legitimación del poder en Valencia ha trabajado en varias ocasiones Narbona 1994, 1996, 2003, 2004, entre otras.

${ }^{14} \mathrm{Se}$ ha descartado la posibilidad incluir más ejemplos procedentes de otros lugares la Corona debido a la falta de noticias o publicaciones relacionadas con la intervención directa de los poderes laicos en este periodo -el uso de documentación inédita fuera del estudio de caso excedía el propósito de este trabajo-, así como a la limitación razonable de la extensión del artículo.
} 


\section{EL DESARROLLO DEL CULTO A SAN LORENZO \\ EN LA CIUDAD DE HuESCA (SIGLOS XIII-XV). Un ESTUdiO DE CASO}

Durante la segunda mitad del siglo XIII, Huesca era una ciudad de unos 8.000 habitantes, una cifra que la colocaba entre las diez más grandes de la Corona de Aragón ${ }^{15}$. Contaba con un entorno agrario de considerable riqueza ${ }^{16}$, una pequeña pero activa industria textil ${ }^{17} \mathrm{y}$ una situación especial en el norte del valle del Ebro, en relación especialmente con Zaragoza ${ }^{18}$. Si bien dispuso de un precoz gobierno urbano, instaurado ya a finales del siglo anterior, basado en el sistema de jurados, fue durante los años centrales del Doscientos cuando comenzó a desarrollarse una serie de experimentos que permitieron pasar de la pura cooptación de los miembros que componían las magistraturas colegiadas a un sorteo entre un grupo numeroso de personas escogidas por parroquias, experimentos que se iniciaron en 1261 y concluyeron provisionalmente en $1311^{19}$. Esta sucesión de propuestas, aprobadas por el rey, refuerzan la idea de que la elite oscense estaba buscando un modelo de organización política en el contexto de un claro crecimiento económico y una visible diversificación social. Hay que subrayar que la ciudad presenta una historia turbulenta durante este periodo, en el transcurso del cual se subleva contra Jaime I en los años 1220 y vuelve a hacerlo contra Pedro III en 1283 en el marco de la Primera Unión ${ }^{20}$. Los años finales de esta centuria coinciden además con un largo enfrentamiento entre el concejo urbano y los canónigos de la catedral surgido a raíz del proceso de secularización del cabildo catedralicio. El abandono de la forma de vida comunitaria de los miembros del cabildo, que podría parecer a primera vista una decisión meramente eclesiástica, para los ciudadanos de Huesca involucraba cuestiones que les afectaban directamente, como la situación fiscal en la que quedaban los clérigos al convertirse en seculares dentro de las nuevas contribuciones vecinales, o aspectos ideológicos relacionados con la moralidad de los canónigos, que dejaban de convivir en un entorno controlado para hacerlo en sus casas y de manera independiente, lo que podía repercutir en la imagen pública de la ciudad ${ }^{21}$. Por otro lado, las disputas por el poder municipal entre los nobles con residencia

\footnotetext{
${ }^{15}$ Utrilla 1977.

${ }^{16}$ Laliena 1994.

${ }^{17}$ Utrilla 1995; Riera 2005.

${ }^{18}$ Durante la Baja Edad Media, hay indicaciones de un papel significativo de esta ciudad como centro de redistribución mercancías procedentes del Mediterráneo, Sesma 2012.

${ }^{19}$ Iranzo 2004, pp. 271-279 y 239-243; Laliena 2010.

${ }^{20}$ González 1975, 1977; Laliena 1989.

${ }^{21}$ Durán 1985, pp. 112-124.
} 
urbana o "infanzones" y ciudadanos no se aplacaron hasta 1322, cuando se llegó a un acuerdo que permitió a los primeros retener algunos puestos en el gobierno municipal ${ }^{22}$. A pesar de estos conflictos, las fuentes evidencian una unanimidad en las decisiones tomadas por el concejo que intervenía de forma creciente en múltiples aspectos de la vida social urbana ${ }^{23}$.

Paralelamente, es posible observar en la ciudad diversos tanteos relacionados con la eclosión de fenómenos de religión cívica semejantes y contemporáneos a los que se estaban verificando en otras ciudades, tanto del mundo mediterráneo como del norte de Europa. Uno de los más interesantes es el culto a la Virgen en una ermita cercana al casco urbano, Santa María de Salas, un santuario fundado hacia finales del siglo XII o principios del XIII, que se convirtió en un centro de peregrinación de cierta importancia. En 1203, el obispo y el prior del monasterio urbano de San Pedro el Viejo peleaban por la titularidad del templo ${ }^{24}$, por lo que la Virgen de esta iglesia debía de gozar ya de cierto prestigio, quizás como consecuencia de la atribución de algunos milagros, que más tarde serían ampliamente difundidos gracias a las cantigas que les dedicó Alfonso $\mathrm{X}^{25}$. Tras múltiples disputas, el monasterio fue compensado con algunas heredades y diezmos y Santa María de Salas pasó a formar parte de la jurisdicción de la catedral ${ }^{26}$. Las primeras donaciones populares a este santuario se inician hacia 1206 y crecen de manera considerable hacia el segundo cuarto de siglo, formando un conjunto tan numeroso que, cuando, en la década de 1270, la catedral compiló el cartulario conocido como Libro de la Cadena se incluyó un dosier con las concesiones realizadas a Santa María de Salas $^{27}$. Los peregrinos que acudían a este santuario recibieron la protección de Jaime I en $1222^{28}$, que ordenó que no fueran molestados bajo pena de mil maravedíes. Los visitantes procedían no sólo del reino de Aragón,

\footnotetext{
${ }^{22}$ Laliena 1988, n 116; Iranzo 2004, pp. 250-260. Los “infanzones" eran jurídicamente nobles y estaban exentos fiscalmente, lo que hacía que fueran rechazados por los ciudadanos a la hora de participar en los cargos del gobierno urbano ya que no contribuían económicamente en las contribuciones vecinales, Iranzo, Laliena 1991. Este problema, general en el reino de Aragón, no tuvo la misma solución en todas las ciudades: así, en Zaragoza, quedaron excluidos del gobierno urbano, Mainé 1999.

${ }^{23}$ Diversas ordenanzas municipales entre 1280 y 1349 regulan aspectos concretos de la actividad municipal y reflejan la capacidad administrativa del concejo y la cohesión institucional a la que se hace referencia, Laliena 1988, $\mathrm{n}^{\circ}$ 47- 51, 57, 59-60, 72-74, 113, 120, 182.

${ }^{24}$ Balaguer 1957; Aguado 1987.

${ }^{25}$ Aguado 1987; Alfonso X, Cantigas de Santa María, ed. Mettmann.

${ }^{26}$ Montaner, Laplana 2016, $\mathrm{n}^{\circ} 102$.

${ }^{27} \mathrm{ACH}$, Libro de la Cadena, $\mathrm{n}^{\mathrm{o}} 1-85$.

${ }^{28}$ De este documento se conservan dos copias idénticas pero con diferente datación, una fechada en 1222 (AHPZ, Comisión Provincial de Monumentos de Zaragoza, carp. 53/0241) y otra en 1234 (ACHU, A. 9-205). Quizás esta disparidad se deba a que el segundo pergamino es una renovación posterior del privilegio.
} 
sino también del sur de Francia, puesto que, en 1362, Santa María de Salas pagó al colector de la Cámara apostólica parte de sus tributos en moneta sterlinguorum y obolos burdegalenses bonos et malos, la moneda de la Gascuña inglesa ${ }^{29}$. Todo esto indica una notable efervescencia alrededor de la imagen de la Virgen y de sus poderes: algunos de sus milagros, tal y como los narra el monarca poeta, hacen referencia a acontecimientos producidos durante la conquista de Valencia, prisioneros liberados y portentos similares, pero también a asuntos más cotidianos como la concepción de niños por parte de parejas infértiles y la resurrección de muertos ${ }^{30}$. La fama de la imagen de Salas como milagrosa está recogida en la documentación desde al menos 1227, ya que las donaciones incluían siempre alusión a las multas misericordias et miracula que diversis modis Dominus noster Ihesus Christus, redemptor noster, cotidie facit in ecclesie beatissime et gloriose semperque Virginis Marie, genitricis eius, de Salis $^{31}$.

En la segunda mitad del siglo XV todavía hallamos algunas donaciones aisladas al santuario ${ }^{32}$, pero son tan escasas que no permiten saber si contaba con el mismo atractivo que en los dos siglos precedentes. En cualquier caso, la vitalidad de este culto marial en el periodo que nos interesa queda de manifiesto en la iglesia que todavía muestra algunos elementos de interés arquitectónico de su periodo de esplendor. Se trata de una obra de la primera mitad del siglo XIII que, en su momento, estaba compuesta por tres naves cubiertas por un techumbre de madera, que fueron rehechas en 1722. Conserva, no obstante, una portada magnífica y una cabecera plana de su traza original, así como restos de pinturas fechables a principios del Trescientos ${ }^{33}$.

Sin embargo, a pesar de que este culto gozó de evidente popularidad, no cuajó como un elemento significativo en la definición de la identidad urbana, en parte porque la iglesia era competencia del obispo, pero también debido a que la Virgen no es la figura de preferencia a la hora de elegir un patrón que representase al conjunto urbano. Tal como señala Lorenzo Tanzini ${ }^{34}$, los

\footnotetext{
${ }^{29}$ ASV, Instrumenta Miscellanea 2.262, f. 1v. Agradezco a Guillermo Tomás Faci la localización de este documento.

${ }^{30}$ Alfonso X, Cantigas de Santa María, ed. Mettmann.

${ }^{31}$ Montaner, Laplana 2016, $\mathrm{n}^{\mathrm{o}}$ 214, 215, 218, 219, 222, 231, 255, 293. La parte final se modificaría a partir de los años treinta del mismo siglo por "in ecclesie Beate Marie de Salis de Osca" (ibidem, $\mathrm{n}^{\circ} 298,324,333$ ).

${ }^{32}$ Pérez 2015, pp. 436, 616, 733 y ss., documenta tres donaciones testamentarias a Santa María de Salas por parte de tres mujeres de la ciudad de Huesca. No obstante, hay que señalar que Pedro IV se apoderó de todos los objetos de plata de este templo durante la Guerra de los Pedros, y que en 1367 resarció al santuario con un excepcional retablo en plata que todavía se conserva, Balaguer 1957, p. 216.

${ }^{33}$ San Vicente, Canellas 1971, p. 346.

${ }^{34}$ Tanzini 2016.
} 
gobiernos ciudadanos preferían relacionar sus orígenes con santos y héroes (o emperadores en el caso de Italia) que hubieran nacido en la ciudad, ya que permitían remontar la comunidad a un pasado a la vez remoto y glorioso, y se configuraban como una herramienta más útil para crear un sentimiento de identidad. La "conciudadanía" que cabe atribuir a estos personajes era un eficaz factor de adhesión emocional y contribuía también a potenciar los valores comunitarios ligados a los rituales religiosos desarrollados alrededor de estas figuras. En efecto, esto es lo que ocurre en Huesca. Durante la segunda mitad del siglo, se consolida la adoración al santo romano Lorenzo como el patrón que anudaba los elementos simbólicos de la piedad y la caridad -esos eran los signos distintivos de este mártir- y la imagen de sí misma de la ciudad, compatibilizada con la presencia en un tono menor de san Vicente, ambos considerados desde entonces por la tradición como nativos de Huesca.

Aunque los santorales altomedievales ya recogían la existencia de estos dos personajes, ampliamente conocidos en el mundo visigodo gracias a sus impresionantes martirios ${ }^{35}$-Lorenzo murió en Roma quemado en una parrilla y Vicente en Hispania tras sufrir numerosas torturas-, las primeras alusiones a su procedencia oscense datan de mediados del siglo XIII, de la mano del poeta riojano Gonzalo de Berceo $(\dagger c a .1264)^{36}$. El poema hagiográfico dedicado a la vida del santo, el Martyrio de san Laurencio, comienza así: Vicencio e Laurencio, omnes sin depresura, / ambos de Uesca fueron, dizlo la escriptura ${ }^{37}$.

Es difícil, por ahora, saber cuáles fueron las fuentes de Berceo para hacer tales afirmaciones y, de hecho, habrá que esperar hasta el siglo XV, con Vicente Ferrer, para encontrar otras referencias externas que hagan alusión al nacimiento de Lorenzo en Huesca ${ }^{38}$, ya que Jacobo de la Vorágine ${ }^{39}$, en su Leyenda Dorada, o Juan Gil de Zamora ${ }^{40}$, en Legende Sanctorum, se limitaron a comentar el carácter hispano del santo. En lo que respecta a las fuentes locales, la primera mención explícita sobre la naturaleza oscense de Lorenzo data del primer cuarto del siglo XIV y se encuentra en los estatutos de la cofradía de San Lorenzo de Loreto, un pequeño núcleo de población cercano al casco urbano de Huesca. En concreto, entre 1327 y 1336 se modificaron algunas de las ordenanzas de esta cofradía y se renovó una que obligaba a los

\footnotetext{
${ }^{35}$ Fábrega 1953, pp. 68-73 y 181-183.

${ }^{36}$ Garcés 2008, pp. 31-32.

${ }^{37}$ Tesauro 1992, p. 463.

${ }^{38}$ Garcés 2015, p. 205.

${ }^{39}$ Vorágine 1982, pp. 461-473.

${ }^{40}$ Gil de Zamora, Juan, Legende sanctorum et festivitatum aliarum de quibus Ecclesia sollempnizat, ed. Martín Iglesias, Otero Pereira, pp. 503-516.
} 
cofrades y cofradesas a reunirse el domingo antes de la fiesta de san Martín en una comida de hermandad y celebrar al día siguiente misa de requiem, tras la cual debían rezar ante las tumbas de los padres de Lorenzo situadas en esta localidad $^{41}$. Lorenzo ha sido considerado natural de Loreto por el imaginario popular, con la excepción de un breve periodo del siglo XVII en el que algunos eruditos locales trataron de cambiar su lugar de nacimiento a Huesca ${ }^{42}$ y llegaron a borrar incluso algunos de los testimonios escritos que aludían a la existencia de las tumbas de sus padres en el cementerio de Loreto ${ }^{43}$. Carlos Garcés $\mathrm{Manau}^{44}$ ha señalado que la asociación del mártir con este pequeño lugar puede estar relacionado con la hominimia entre Loret y Lorent, la forma aragonesa de Lorenzo. Es bastante probable que esta tradición ya existiera hacia 1250, periodo del que proceden las primeras noticias sobre el origen oscense de Lorenzo. En lo que respecta a san Vicente, el Rolde de la Cofradía de San Vicente del Sepulcro y San Lorenzo de Loreto (ca. 1400) copia un documento del siglo XIII, del que fue testigo el ciudadano de Huesca, García López de Anzano, que hace referencia a que la iglesia dedicada a este mártir fue construida en su casa natal ${ }^{45}$.

De todas formas, tanto la opción por san Lorenzo, que era un prototipo del clérigo modélico -al ser el diácono encargado de regir las finanzas de la Iglesia-, como la difusión de la creencia en su origen oscense hasta llegar a Gonzalo de Berceo resultan difíciles de explicar. Lo mismo ocurre con la adopción de Vicente, que era un santo relacionado con Zaragoza, de cuya catedral fue titular durante el periodo altomedieval y al que se atribuían milagros importantes en aquella época, y unido también con Valencia. Que esta multiplicidad de intereses en torno a Vicente cuajase solo o prioritariamente en la ciudad del Turia y el santo quedase relegado a una posición secundaria en Huesca es razonable por las diferencias entre ambas capitales, pero resulta menos fácil saber por qué el patriciado urbano oscense tendió a pensar que un santo tan institucional y tan difundido era adecuado para representar también a la ciudad, aunque fuera a un nivel más secundario. Es probable que tanto en lo que se refiere a Lorenzo como a Vicente, se trate de un fenómeno relacionado con el tráfico de reliquias y una cuestión de oportunidad: en la coyuntura en que la configuración institucional y cultural de las ciudades del Mediterráneo requería elegir un santo al que rendir culto y que actuase como protector de la urbe, Lorenzo captó el interés de las elites oscenses y fue incorporado con

\footnotetext{
${ }^{41}$ APSLH, Rolde de la Cofradía de San Lorenzo de Loreto, plágula 7.

${ }^{42}$ Fontana 2008.

${ }^{43}$ AHPH, Rolde de la Cofradía de San Lorenzo y San Vicente del Sepulcro, f. 39r.

${ }^{44}$ Garcés 2008, pp. 36-37.

${ }^{45}$ AHPH, Rolde de la Cofradía de San Vicente del Sepulcro y San Lorenzo de Loreto, f. 9r.
} 
decisión a los rituales religiosos, con la suficiente visibilidad como para que el proyecto fuera conocido en el entorno del valle del Ebro y en San Millán de la Cogolla.

En este proyecto destaca la construcción de sendos templos en honor a estos dos santos, que se erigen a comienzos del siglo XIII. Las noticias más tempranas las encontramos en una compraventa realizada enero de 1214, donde figura entre los testigos el prior de San Vicente de Huesca ${ }^{46}$, y en un documento de diciembre 1217, en el que un matrimonio vende unas casas que tienen fuera de la muralla de piedra circa ecclesiam sancti Laurenti ${ }^{47}$. Unos años más tarde, en 1228, los clérigos de Montearagón donaron a Pedro de Cuende y su mujer Gila las primicias y limosnas de la iglesia de Sancti Laurencii de Loreto. Por su parte, la de San Vicente existía ya en 1198, como indica un documento de esa fecha ${ }^{48}$. Los templos actuales son de época moderna, por lo que poco más se puede aportar al respecto, excepto señalar que hacia 1235 las festividades de san Lorenzo y san Vicente eran ya una fecha señalada en el calendario oscense, ya que algunos documentos establecían el pago de los censos enfitéuticos en esas fechas ${ }^{49}$.

En este momento, entre los inicios de la década de 1240 y los últimos años del siglo XIII, se crean en la ciudad dos cofradías colocadas bajo la advocación de Lorenzo, una de ellas radicada en la iglesia de Loreto -a la que ya se ha hecho mención-, y una tercera asignada a Vicente ${ }^{50}$. La presencia de miembros de la elite oscense durante este medio siglo y, a partir de ahí, durante toda la Baja Edad Media en las listas de cofrades y cofradesas sugiere que detrás de ellas había una suerte de estrategia para establecer a este santo, como elemento central en la construcción ideológica de la colectividad urbana ${ }^{51}$. En concreto para el siglo XIII, la prosopografía de los ciudadanos de Huesca que he preparado en el marco de mi tesis, permite hacer esta afirmación con seguridad, mientras que las indicaciones procedentes de la obra de María Teresa Iranzo van en esta línea en lo que se refiere al periodo posterior a mediados del Trescientos ${ }^{52}$. Estas cofradías organizaban diversos actos públicos de índole religiosa en honor al santo, tales como comidas de hermandad, gestos

${ }^{46}$ Montaner, Laplana 2016, $\mathrm{n}^{\circ} 4$.

${ }^{47}$ Ibidem, $\mathrm{n}^{\circ} 75$.

${ }^{48}$ AHN. Clero, carp. 617, $\mathrm{n}^{\circ} 1$. El prior de esta iglesia divide una viña recién plantada con Pere Gascón. En 1253, la iglesia contaba con un altar dedicado a san Antonino: AHN. Clero, carp. $617, \mathrm{n}^{\circ} 2$.

${ }^{49}$ Montaner, Laplana 2016, $\mathrm{n}^{\circ} 341$.

${ }^{50}$ APSLH, Rolde de la Cofradía de San Lorenzo de Loreto; BPH, ms. 139 Rolde de la Cofradía de San Lorenzo; AHPH, Rolde de la Cofradía de San Vicente del Sepulcro y San Lorenzo.

${ }^{51}$ García (en prensa).

${ }^{52}$ Iranzo 2004, apéndices prosopográficos. 
específicos de caridad y procesiones. Estas últimas tenían que estar organizadas por las autoridades laicas y eclesiásticas, ya que eran las encargadas de gestionar el espacio público por el que trascurrían y, además, constituían una representación visual de la protección que el santo ofrecía a la ciudad. Aunque para esta época no disponemos de fuentes que nos aclaren estos aspectos, podemos tomar como referencia la documentación municipal del siglo XV que especifica algunos de los gastos que corrían a cargo del concejo en diversas celebraciones públicas. Por ejemplo, para la festividad de san Lorenzo pagaba parte de las corridas de bueyes y de los sueldos de flautistas y tamborileros contratados para tocar durante la procesión, así como funciones teatralizadas de los santos Lorenzo y Vicente, que probablemente representaban sus respectivos martirios ${ }^{53}$. También un Ceremonial para los justicia, prior y jurados de la ciudad de Huesca, compilado por Diego de Aynsa a principios del siglo XVII, que refleja prácticas bajomedievales, nos acerca a los preparativos que había detrás de estos acontecimientos y describe cómo los jurados y los ciudadanos formaban parte activa de las procesiones y los festejos en honor a los dos santos patrones ${ }^{54}$.

Solamente un análisis detenido de las reformas litúrgicas de los siglos XIII y comienzos del XIV permitirá avanzar en el conocimiento de la forma en que Lorenzo se afianzó como el santo propio de la ciudad, pero cabe pensar que la coincidencia de algunos acontecimientos marca el momento en que cristalizó. El 10 de agosto 1307, fiesta de san Lorenzo, Jaime II hizo entrega a la iglesia parroquial de una reliquia del dedo del mártir que había traído desde Roma. Ese mismo día se sumó a la cofradía de san Lorenzo de Huesca, junto con algunos nobles de su entorno, entre los que se encontraba un miembro del linaje los Azlor, quizá hermano del actual obispo ${ }^{55}$. Las ceremonias que acompañaron esta entrega, junto con la propia reliquia y el definitivo impulso de la cofradía ratificaron la posición de san Lorenzo como patrón de la ciudad, junto con otras medidas tomadas por el propio monarca. En el tiempo en que Jaime II estuvo residiendo en la ciudad, entre el 23 de mayo y el 21 de agosto de $1307^{56}$, mostró una considerable preocupación por fomentar este culto a través de varias concesiones, algunas de carácter menor, y otras más significativas. El 2 de julio, prohibió a los herreros musulmanes, que vivían cerca de la iglesia de San Lorenzo, que trabajaran en domingo y otras festividades, debido a las molestias que ocasionaban para la celebración

\footnotetext{
${ }^{53}$ Ibidem, p. 526.

${ }^{54}$ Aynsa 1620, f. 5 y ff. 26-27.

${ }^{55} \mathrm{BPH}, \mathrm{ms} .139$, ff. 5v-6r.

${ }^{56}$ Estal 2009, pp. 335-339.
} 
de la liturgia ${ }^{57}$. Un día después, hacía entrega de unos talleres artesanales que tenía en propiedad compartida con el noble Lope de Jasa, para que se construyera una plaza que permitiera ver el templo con holgura: et eorum patium sit semper atque remaneant franche et libere pro platea vel [roto] ecclesie memorate [Sancti Laurentii] ${ }^{58}$, cuya edificación gótica había acabado recientemente ${ }^{59}$. Unos meses más tarde, encontramos también otra noticia que, aunque escapa a la relación entre Lorenzo y Huesca, pone de manifiesto la especial dilección que tenía Jaime II con el mártir y contribuye a entender los motivos de la protección que despliega el rey con la iglesia laurentina y, por extensión, la consolidación del culto cívico en la ciudad: el 29 de agosto, cambió con el monasterio de San Victorián de Sobrarbe la iglesia de San Salvador en Huesca por una renta anual de 400 sueldos, con obligación del limosnero del convento de dar 10 sueldos en la fiesta de este santo para una comida especial y con la condición de decir misa en honor al santo y por la salud del rey y, tras su muerte, celebrar un aniversario anual ${ }^{60}$. Si bien es cierto que se trata de ejemplos de una intervención regia, en este caso orientada hacia la memoria real en un monasterio de antigua tradición ${ }^{61}$, es importante subrayar que había unos intereses compartidos entre Jaime II y el concejo a la hora de patrocinar el culto a san Lorenzo, tal y como demuestra el hecho de que el rey ingresara como miembro en una cofradía de corte ciudadano.

Todo esto tuvo lugar probablemente cuando se incorporaron las esculturas de los santos Lorenzo y Vicente a la galería de apóstoles de la portada de la catedral, junto con los escudos heráldicos de la ciudad y del obispo Martín López de Azlor, bajo la escultura de la Virgen dominando la Lujuria. Recientemente se ha planteado que el tímpano fue terminado en los primeros años del Trescientos ${ }^{62}$ y no, como sugerían otros autores, en 1338, a manos de un maestro de obras llamado Guillermo Inglés ${ }^{63}$. Conviene destacar, además, que el concejo contribuyó económicamente a la obra de la nueva catedral, ya que las ordenanzas municipales de finales del siglo XIII destinan parte del importe de las multas para tal efecto ${ }^{64}$. En este sentido, es factible que el

\footnotetext{
${ }^{57}$ De este documento se conservan dos copias, una en el AMHU (Laliena 1988, $\mathrm{n}^{\circ}$ 85) y otra en el ACA (Ferrer 1987, nº 8).

${ }^{58}$ ACA, Cancillería, Registro 204, f. 69r.

${ }^{59}$ Garcés 2008, p. 52.

${ }^{60} \mathrm{AHN}$, Clero, carp. $775, \mathrm{n}^{\circ} 8$.

${ }^{61}$ Sobre el interés por parte de la monarquía en rodearse de reliquias que representaran la doble naturaleza de la dimensión del poder real: Español 2001, pp. 109-118.

${ }^{62}$ Garcés 2014, pp. 260 y ss.

${ }^{63}$ Durán 1991, p. 83.

${ }^{64} \mathrm{Se}$ trata de normativas establecidas en un periodo conflictivo, en el que el concejo había implantado un sistema de defensa de la ciudad por apellido así como una serie de
} 
diseño de la portada fuera un símbolo de la reconciliación entre el cabildo catedralicio y el concejo, cerrando así el conflicto en torno al proceso de secularización de los canónigos de la catedral que había durado varios decenios y al que había puesto fin el papa Bonifacio VIII ${ }^{65}$. En esta disputa, los jurados oscenses defendían que los canónigos debían vivir de forma regular según la regla agustiniana, mientras que estos, apoyados por el obispo, se juramentaron en diversas ocasiones para mantener el modo de vida secular, que habían implantado hacia $1265^{66}$.

Por otra parte, al mismo tiempo que se consolida la devoción popular de Lorenzo podemos observar cómo se va construyendo una narración en torno a la vida del santo que se relaciona con determinados lugares de la ciudad. Uno de ellos es la creación del panteón familiar que incluye a sus padres, Orencio y Paciencia, y a su hermano gemelo también llamado Orencio. La primera referencia a los progenitores del mártir la encontramos en los estatutos de la Cofradía de San Lorenzo de Loreto, ya citada. El mandato a los cofrades de acudir tras la comida conjunta a absolver la fuessa del padre et de la madre de senyor sant Lorent, et todo el ciminterio de aquel [lugar $]^{67}$, indica que estaba forjándose un relato legendario alrededor del santo. Aunque los padres todavía carecen de nombre explícito, según Ramón de Huesca existía en la catedral un martirologio fechado en el siglo XIV, que no ha llegado hasta nuestros días, que indicaba que el IV idus Augusti. Laurentius ex patre Orentio et matre Patientia, Oscae ortus est ${ }^{68}$. No obstante, la devoción de san Orencio y santa Paciencia se desarrollará extensamente en época moderna puesto que fue en los últimos años del siglo XVI cuando se trasladaron a Huesca los cráneos de estos dos santos, conservados en sendos relicarios de plata $^{69}$. Los bolandistas recogieron también este testimonio sobre los padres de Lorenzo en sus Acta Sanctorum, junto con la idea del nacimiento del santo en Huesca ${ }^{70}$.

límites o estancos del núcleo urbano que no podían traspasarse sin autorización, Iranzo 2004 pp. 218-219. En este sentido, en 1288 se establece una multa de 50 maravedíes por sobrepasar los estancos, de los cuales la tercera parte sería para la obra de la catedral; y además obligaba a aquellos obreros de la catedral, que no estuvieran trabajando por ser día festivo, a acudir al llamamiento bajo pena de 5 sueldos, destinados también para la catedral, Laliena $1988, \mathrm{n}^{\circ} 59$.

${ }^{65}$ ASV, Reg. Vat. 50, ff. 165v-166r.

${ }^{66}$ Durán 1985, pp. 112-124.

${ }^{67}$ AHPH, Rolde de San Vicente del Sepulcro y San Lorenzo de Loreto, plágula 7.

${ }^{68}$ Huesca 1792, p. 276.

${ }^{69}$ Morte 1994, p. 220.

${ }^{70}$ Sollerio et al. 1867, p. 485. 


\section{MANiFESTACIONES DE RELIGIÓN CíviCA EN LA CORONA DE ARAGÓN}

El fenómeno que aquí analizo para la ciudad de Huesca no es de ningún modo excepcional, sino que, como he señalado anteriormente, es parte de una tendencia habitual en las ciudades europeas. Por tanto, para contextualizarlo es necesario incidir en algunos aspectos de la remodelación de los cultos urbanos que se insertan en el ámbito de la religión cívica por parte de los concejos de otras ciudades de la Corona de Aragón, que comparte unas características comunes con el caso oscense, no sólo por su coincidencia en el tiempo, sino también por la forma en la que se desarrolló esta peculiar relación identitaria con los santos patronos.

En Barcelona, la veneración a la mártir romana Eulalia arranca de una época muy temprana y es un ejemplo característico de la utilización de cultos altomedievales reciclados en la plena Edad Media. Aunque en los alrededores de la ciudad condal existieron varias iglesias dedicadas a santa Eulalia, entre ellas una importante canónica agustiniana fundada en el siglo XII ${ }^{71}$, la devoción se consolidó en la catedral. Con toda probabilidad, la inventio del cuerpo de la santa tuvo lugar en el siglo IX, tal y como narran las leyendas redactadas en el siglo XIV: el obispo Frodoino encontró supuestamente los restos de esta santa junto a la iglesia de Santa María del Mar y los trasladó a la catedral advocada a la Santa Cruz y a la propia Eulalia, donde permanecieron hasta la construcción del nuevo templo ${ }^{72}$. Si bien es posible que el culto de esta mártir tuviera continuidad durante todo el periodo medieval, tal y como plantea Cabestany i Fort ${ }^{73}$, lo cierto es que esta idea tiene connotaciones ideológicas en el sentido de preconizar una adhesión de la Barcelona del centro de la Edad Media a un lejano pasado godo, un clásico planteamiento de la historiografía catalana de mediados del siglo $\mathrm{XX}^{74}$. En todo caso, es evidente que en el siglo XIV, como muy tarde, se produjo una renovación del atractivo de esta santa para la ciudad condal. Fue en estos años cuando se procedió a la construcción de la catedral gótica, financiada en parte por el gobierno urbano, y se diseñó una cripta para guardar los restos de Eulalia, que pasaron a conservarse en un nuevo sepulcro ${ }^{75}$. Se efectuaron dos traslados oficiales de los huesos, uno provisional en $1337^{76}$, en el cual el obispo, acompañado de los canónigos,

\footnotetext{
${ }^{71}$ Jaspert 1996.

${ }^{72}$ Garí 2010; Cabestany 1996.

${ }^{73}$ Ibidem, plantea que el hallazgo del cuerpo de santa Eulalia vinculaba una devoción coetánea con una santa ya venerada en tiempos de los visigodos.

${ }^{74}$ Abadal 1974.

${ }^{75}$ Bassegoda 1984.

${ }^{76}$ AHB, 1A-377.
} 
ciudadanos, jurats y consellers, los colocó en la nueva sacristía; y el definitivo en $1339^{77}$, que coincidió con la consagración del nuevo edificio, en una ceremonia encabezada por el rey Pedro IV. En este último acto, santa Eulalia fue conducida en procesión por las calles de Barcelona para ser depositada en un mausoleo de mármol, decorado con imágenes que representaban el martirio, la invención y traslado de los restos de la santa ${ }^{78}$. Es también en este momento, como he señalado anteriormente, cuando se redactaron los versos que narran el fortuito hallazgo del cuerpo de la mártir por el obispo Frodoino ${ }^{79}$.

Unos años más tarde, podemos encontrar testimonios directos del creciente apego que suscitaba del ámbito eclesiástico. Por ejemplo, en 1345, el mercader Jaume Mitjavila iniciaba su libro de cuentas con la siguiente invocación: En nom de nostre Senyor sia e de la benuyrada beneyta mare sua madona Santa Maria e de la beneyta madona Santa Eularia, cors sant de Barchelona, e de tota la cort selestial ${ }^{80}$. En 1383 se constituyó una cofradía de mercaderes catalanes con sede en el convento de franciscanos de Zaragoza en honor a santa Eulalia, cuyos miembros solicitaban al rey que aprobara la fundación con estas palabras:

supliquen los mercaderes cathalans habitantes en la ciudat de Çaragoça que con ella, senyor, per devocio que han en la verge Sancta Eulalia, cors sant de Barchinona (..) haven en lur proposit (...) fer una confraria sots invocació de la dita verge ${ }^{81}$.

Para entonces, parece claro que una parte de la elite mercantil barcelonesa profesaba un aprecio considerable a esta santa y su adoración constituía un elemento identitario significativo.

Tarragona es un caso particular debido a la doble jurisdicción ejercida por la Iglesia y la monarquía en este territorio, una situación que a lo largo de la Edad Media dio lugar a no pocas luchas por el control de la ciudad y su campo $^{82}$. El origen de santa Tecla, reverenciada como un modelo de castidad femenina, está unido a la consolidación del poder catedralicio a principios del siglo XII ${ }^{83}$. En efecto, la primera alusión a Tecla como titular de la metrópoli se encuentra en una bula papal del año 1091, en la que el pontífice ponía bajo

\footnotetext{
${ }^{77}$ AHB, 1A-385.

${ }^{78}$ Bassegoda 1973,p. 141.

${ }^{79}$ Garí 2010.

${ }^{80}$ Hurtado 2005, f. 1r.

${ }^{81}$ Falcón 1997, pp. 109-110.

82 Juncosa 2015, pp. 79 y ss.

${ }^{83}$ Sobre el culto a santa Tecla, Pérez 2005-2006.
} 
su protección a la Tarragona ${ }^{84}$. No obstante, su culto cobró un nuevo sentido en el siglo XIV con el traslado las reliquias de la santa desde Armenia. Este suceso fue orquestado por Jaime II con la intención de aumentar su devoción en la ciudad, ya que con esas palabras se dirigía al monarca de Cilicia en la carta que escribió en 1319 para tal efecto:

ac exaltacionem et gloriam predicte beate Thecle virginis, attento quod nedum ad huiusmodi reliquias in hiis partibus, verum etiam ad totum ipsius virginis corpus erga partes, ubi tumulatum quiescit, harum parcium fidelium incolarum devocio per augebitur ${ }^{85}$

El brazo de Tecla entró en Tarragona el 19 de junio de 1323, coincidiendo con la consagración del nuevo edificio catedralicio, lo que impulsó la identificación de la ciudad con esta mártir ${ }^{86}$. El cabildo y el consell de la ciudad colaboraron en las celebraciones, así como en los gastos del transporte de la reliquia ${ }^{87}$. Unos años más tarde, tal y como recoge una Consueta de la catedral de 1369 , la procesión anual en honor a la santa estaba ya afirmada $^{88}$. En este acontecimiento participaban los ciudadanos y los miembros del cabildo junto a los representantes de las cofradías de la ciudad, que desfilaban en un orden determinado, encabezados por la senyera del consell ${ }^{89}$. Las actas municipales detallan las teatralizaciones que tenían lugar en dicha ocasión, que incluían músicos, juglares, doncellas con palmas, un serafín y un diablo entre otros personajes, así como ochenta personas que caminaban junto a los restos de la santa a las que se les proporcionaba alimentos ${ }^{90}$. Tanto la contratación de los artistas como los gastos derivados de los materiales de estas actuaciones (vestimentas, adornos, cirios, etc.) corrían a cargo de la hacienda municipa ${ }^{91}$. Todo esto es prueba suficiente de que había una clara intención del gobierno urbano en fomentar esta festividad como un elemento de cohesión del tejido social urbano. Un ejemplo de la popularidad de Tecla en el siglo XV lo encontramos en un pregón de la ciudad de 1422 que comienza así: En nom de Deu sie e de la verge Madona sancta Maria e madona sancta Tecla, cors sant de Terragona ${ }^{92}$. Además,

\footnotetext{
${ }^{84}$ Juncosa 2015, p. 84.

${ }^{85}$ García 1922, pp. 44-45.

${ }^{86}$ Pérez 2005-2006, p. 56.

${ }^{87}$ García 1922, pp. 48-50.

${ }^{88}$ Tomás 1963 , pp. $174-175$.

${ }^{89}$ Juncosa 2015, p. 210.

${ }^{90}$ Sanmartí, Companys 2011, p. 22

${ }^{91}$ Sanmartí, Companys 2011, pp. 69 y ss .

${ }^{92}$ Sanmartí, Rius 1995, p. 193
} 
en 1428, el consell financió -al menos en parte- el retablo gótico del altar mayor de la Catedral dedicado a la santa, a través de las multas por malas prácticas de regadío ${ }^{93}$.

Por otro lado, Tecla sirvió también como instrumento ideológico en los momentos de tensión entre el obispado y los poderes laicos. Al menos, en una ocasión que analiza Eduard Juncosa ${ }^{94}$ a través de la leyenda conocida como La bofetada de santa Tecla al rey Pedro el Ceremonioso. Este conocido relato se enmarca en un periodo especialmente tenso de las relaciones entre Pedro IV y el arzobispo tarraconense Pere de Clasquerí y narra cómo la santa se apareció ante el monarca obligándole a arrepentirse por haber querido usurpar a la Iglesia la jurisdicción de Tarragona y su campo. Con independencia de que esta legendaria narración tenga un obvio contenido clerical, no es menos cierto que su eficacia como descripción del éxito de la Iglesia tarraconense en conservar sus derechos depende de la fuerza de la creencia en el patronazgo que ejercía sobre la ciudad. Solo en un medio urbano en el que la devoción a Tecla era amplia y estaba difundida capilarmente, este milagro podía adquirir su carácter ejemplar.

En el ámbito valenciano, del que me referiré exclusivamente a la capital, Rafael Narbona asocia la elección de san Vicente mártir como santo emblemático de la ciudad con un proyecto ideológico creado por la monarquía y relacionado con la conquista ${ }^{95}$. Expone que, tras la ocupación de la ciudad, Jaime I buscó vincular la nueva población inmigrante con el pasado mozárabe a través del culto a este santo, que se convirtió de esta manera en la prueba irrefutable de que el reino valenciano pertenecía legítimamente a los cristianos, a quienes había sido arrebatado injustamente por los musulmanes. Según los relatos hagiográficos, los restos de este mártir, que había sido torturado y muerto en Valencia, una vez arrojados al mar, habían regresado a la orilla, y en el lugar de su aparición se había erigido un santuario. En concordancia con esta narración mítica, Jaime I construyó y dotó un convento y un hospital anexos a la supuesta sepultura del santo, conocida como San Vicente de la Roqueta. De esta forma, en palabras de Narbona, el rey proporcionaba una reliquia original a la providencial conquista que promovía sentimientos patrióticos entre la población recién instalada ${ }^{96}$. El consell municipal valenciano no tardó en adoptar la fiesta en honor al mártir, celebrándola el 22 de enero, en el marco de decisiones semejantes destinadas a conmemorar la propia conquista, como el 9 de noviembre.

\footnotetext{
${ }^{93}$ Ordinacions 1982, p. 59.

${ }^{94}$ Juncosa 2010.

${ }^{95}$ Sobre el culto de san Vicente en Valencia, Narbona 1996.

${ }^{96}$ Narbona 1996, p. 309.
} 
En Aragón, Zaragoza es uno de los casos excepcionales en los que la Virgen acaba por erigirse en el culto tutelar de la ciudad, si bien tardíamente. La primera noticia de la aparición de la Virgen -en realidad, una narración completa del evento legendario- data de finales del siglo XIII, y parece un gesto oportunista del clero zaragozano de la iglesia de Santa María la Mayor, para captar una parte de las corrientes de peregrinación a Santiago -a quien se aparece la Virgen- y las que se preveía que renacieran gracias al jubileo romano de $1300^{97}$. En otras palabras, la deliberada creación de esta tradición era un movimiento estratégico que perseguía incrementar la importancia de este templo, desarrollado dentro del ambiente eclesiástico y poco conectado con las aspiraciones e intereses de las elites locales.

Aunque durante el Cuatrocientos, el Pilar-como poco a poco se fue denominando a esta iglesia- obtuvo cierta adhesión devocional, hay que esperar hasta el siglo XVII para que, en medio de feroces polémicas, su culto supere al de los obispos Valero y Vicente, cuyas reliquias se custodiaban en la Seo, al de la mártir tardorromana santa Engracia y a otras figuras milagrosas, como la virgen del Portillo ${ }^{98}$. Quizás lo más interesante de lo que sucede en esta capital radica en que durante el siglo XIII se redactan textos hagiográficos sobre santos zaragozanos, como la Legenda Cesaraugustana y De revelacione beati Braulii, episcopi Cesaraugustani ${ }^{99}$, con la intención de fomentar este aspecto de la religión cívica. Este último relato contiene el hallazgo de las reliquias de san Braulio por parte de Pedro de Librana, primer obispo de la ciudad (1119-1128) gracias a la milagrosa intervención de san Valero. Son manifestaciones todavía tímidas, que muestran la voluntad de relanzar el culto a un santo de origen zaragozano, Braulio, que, sin embargo, suscitó poco interés, sin duda por tratarse de una iniciativa estrictamente clerical y tal vez porque este erudito obispo visigodo era un personaje dotado de poco atractivo. Braulio encajaba en la imagen de una Iglesia jerárquica y bien ordenada, regida por severos prelados desde la más temprana antigüedad, pero es difícil que esta encarnación de un santo obispo llamase la atención del patriciado urbano. Además, la década de 1280 asistió a un serio problema en el episcopado zaragozano, puesto que uno de los pretendientes al cargo, el conflictivo arcediano Fortún de Bergua, falsificó las bulas que lo nombraban, con el apoyo de una parte del cabildo, participó de manera activa en la Unión de 1283 y acabó por ser destituido ${ }^{100}$. No parece que fuera el momento para escoger a un prelado, por antiguo y venerable que fuese, como santo emblemático de la ciudad. Por

\footnotetext{
${ }^{97}$ Ramón 2014, p. 52.

${ }^{98}$ Ibidem, p. 53.

${ }^{99}$ Martín 2006.

${ }^{100}$ Beltrán et al. 1976, pp. 289-290.
} 
otra parte, la existencia de mártires de época romana y de sus reliquias en la iglesia de Santa Engracia, llevaron a que esta santa fuera considerada patrona de la ciudad en los últimos decenios siglo $\mathrm{XV}^{101}$. Los libros de pregones zaragozanos evidencian este extremo:

Oyt que vos fazen a saber de part de los senyores jurados de la ciudat de Caragoça que como cras miercoles sea la fiesta de senyora santa Engracia, patrona d'esta ciudat, et sea acostumbrado cada un anyo en la dicha festividat fazer procession general a la yglesia de Senyora Santa Engracia et sea voto de la ciudat ${ }^{102}$.

No obstante, santa Engracia no podía producir un efecto de patronazgo duradero en una época anterior a este periodo, puesto que la iglesia dependía desde el siglo XII de la diócesis Huesca, no del obispado de Zaragoza, lo que creaba una dificultad importante, habida cuenta de los largos pleitos que provocó esta intrusión oscense ${ }^{103}$. La dispersión devocional entre estos distintos focos de religiosidad aseguró la continuidad de san Valero, del que se conservaba la cabeza en la catedral desde $1171^{104}$, como figura central en el panorama religioso de esta ciudad. Valero contaba además con una cofradía muy temprana en su honor; las primeras noticias datan de la década de $1240^{105}$. El culto de santo tuvo una gran vitalidad durante toda la Baja Edad Media y buena parte de la Edad Moderna, hasta que, en 1642, el capítulo del concejo nombró a la Virgen del Pilar patrona de la ciudad, cargo que compartiría durante algún tiempo con los propios Valero y Engracia ${ }^{106}$, e incluso, en el caso del primero, hasta la actualidad.

Una vez expuestas estas casuísticas, creo que se pueden extraer algunos paralelismos útiles para el análisis de estas dinámicas relacionadas con la religión cívica. En primer lugar, es evidente que a finales del siglo XIII y principios del XIV se asiste a una progresiva intervención en los cultos urbanos por parte de las elites de las ciudades de la Corona de Aragón. Si bien es cierto que, en ocasiones, los intereses de la monarquía se mezclan con las acciones de los concejos, parece que ambos actores comparten un objetivo común, fomentar la devoción a un personaje concreto a través de la adquisición de reliquias y la organización de ceremonias y procesiones. La figura de Jaime II fue particularmente útil a los

\footnotetext{
${ }^{101}$ Serrano 2014, p. 26.

${ }^{102}$ Barraqué 2008, p. 265.

${ }^{103}$ Montaner, Laplana 2016, $\mathrm{n}^{\circ}$ 518, 583.

${ }^{104}$ Carrillo 1617, pp. 148-149.

${ }^{105}$ Campo 2003, p. 110.

${ }^{106}$ Serrano 2014, p. 60.
} 
concejos, monasterios y catedrales a la hora de coleccionar restos sacrales, según José Hinojosa, puesto que dedicó notables esfuerzos a conseguir estas piezas ${ }^{107}$. No cabe, sin embargo, atribuir el desarrollo de esta piedad cívica exclusivamente al monarca y es necesario entender que su actuación se enmarcaba en una exigencia de la construcción de las identidades colectivas tanto de las ciudades como un cuerpo social como de sus elites dirigentes. Además, es conveniente señalar que no siempre se pueden entender estos fenómenos como exclusivamente laicos, ya que la participación del clero urbano es importante en el desarrollo de las ceremonias religiosas de carácter público, tal y como señala Paola Ventrone ${ }^{108} \mathrm{y}$, en este sentido, tampoco es posible dejar a un lado la constatación de que el reclutamiento de la clerecía de las ciudades era concomitante con el de los gobiernos municipales.

Por otro lado, las razones que conducen a cada ciudad a escoger su propio santo -y la dimensión del culto que recibe- varían y es evidente que subyace siempre una voluntad diferenciadora, es decir, que la elección se realiza mediante una decantación que tiene en cuenta diversos factores y, entre ellos, la especificidad del santo respecto a las demás ciudades o la existencia de cultos antiguos con suficiente arraigo. No obstante, la implementación de estos cultos no siempre es definitiva. Muchas veces se trata de experimentos que no sobreviven al paso del tiempo y una devoción es eclipsada por otra hasta que, por fin, una figura santificada se eleva por encima de las demás. Además, la popularidad de un tipo de santo u otro varía con las modas y el contexto histórico de cada momento. Así, mientras que en las épocas más tempranas triunfan los mártires tardorromanos, en el siglo XIII lo hacen los llamados santos imitables, obispos y abades que no necesariamente han sido ejemplares desde la cuna ${ }^{109}$, como por ejemplo, san Braulio y san Valero en Zaragoza. En la Baja Edad Media, con el auge de las órdenes mendicantes, llegarán los santos contemporáneos originarios de la propia ciudad $^{110}$, como Vicente Ferrer o Pedro Nolasco. No obstante, aunque resulta difícil determinar qué factores son los que van a garantizar la continuidad del patrón, parece que ser un personaje natural de la ciudad o contar con al menos una reliquia reconocida ante la Santa Sede eran elementos necesarios para el éxito.

\footnotetext{
${ }^{107}$ Hinojosa 2006, pp. 133-135.

${ }^{108}$ Ventrone 2012, pp. 240-242, ha analizado la participación de las elites eclesiásticas en este tipo de festejos en algunas ciudades italianas.

${ }^{109}$ Fernández 2005, pp. 481-496.

${ }^{110}$ Rigon 1995.
} 


\section{CONCLUSIONES}

En definitiva, en este periodo asistimos en los territorios peninsulares de la Corona de Aragón a una intensa difusión de los cultos urbanos en el marco de la evolución de las sociedades urbanas, de sus elites y de su identidad propia. Una difusión iniciada por parte de los concejos que buscaba legitimar su autoridad y, a la vez, dotar de cohesión a una comunidad urbana diversa, con una jerarquización cada vez mayor y divida por las clientelas, las diferencias económicas, las afinidades sociales o los intereses profesionales. Este fenómeno, que la historiografía urbana conoce como religión cívica, se basó, entre otras medidas, en la adopción de atributos religiosos, como la figura de un santo protector que pudiera actuar como elemento aglutinante de este conjunto social plural, a través de la construcción de templos, la gestión de reliquias, la formación de cofradías, la organización de ceremonias, procesiones y otros rituales, así como la creación de narrativas hagiográficas y legendarias destinadas a enaltecer la relación del santo o santa con la ciudad.

Dentro de estas dinámicas, Huesca constituye un buen observatorio para la Corona de Aragón ya que cuenta con varios ejemplos de piedad popular que arrancan en el siglo XIII, como la virgen de Santa María de Salas y los santos Lorenzo y Vicente, y posee además una rica documentación desde época muy temprana adecuada su estudio. Como he señalado en este estudio de caso, Lorenzo fue el santo elegido por las elites oscenses para representar al conjunto de la comunidad urbana. El éxito de esta figura quizás se deba, no sólo a su supuesta relación con la historia de la ciudad o al patrocinio real del culto, sino también a los mecanismos de devoción popular establecidos a través de cofradías transversales, que reunían a vecinos y vecinas de diferentes estratos sociales en comidas de hermandad, actos de caridad pública y procesiones. Este y otros problemas deberán ser analizados a partir del empleo de la prosopografía, que permita discernir la implicación de los individuos y familias del grupo dirigente de la ciudad en este proceso cultural. La comparación, aquí iniciada, mostrará seguramente que estos movimientos cívico-religiosos están, además, profundamente relacionados entre sí, en la medida que las ciudades de la Corona formaban parte de redes económicas y culturales que se están comenzando a analizar. 


\section{BIBLIOGRAFÍA CITADA}

Abadal i de Vinyals, Ramon d' (1974), Dels visigots als catalans, Barcelona, Edicions 62.

Aguado Bleye, Pedro (1987), Santa María de Salas en el siglo XIII: estudio sobre las cantigas de Alfonso X el Sabio, Huesca, Instituto de Estudios Altoaragoneses.

Alfonso X, Cantigas de Santa María, ed. W. Mettmann, Madrid, Castalia, 1986-1989.

Andenna, Giancarlo (coord.) (2011), Religiosità e civiltà. Identità delle forme religiose (secoli X-XIV). Atti del Convegno internazionale, Brescia, 9-11 settembre 2009, Milán, Vita e Pensiero.

Aynsa y de Iriarte, Francisco Diego de (1620), Ceremonial para los muy ilustres señores justicia, prior y jurados de la ciudad de Huesca, Huesca, [s.n.].

Balaguer, Federico (1957), Santa María de Salas. Problemas históricos, “Argensola" 31, pp. 203-233.

Barraqué, Jean Pierre (2008), Entre religión real y religión urbana, "En la España Medieval" 31, pp. 249-274.

Barrios Martínez, María Dolores (2004), Documentos de Montearagón: (1085-1205), Huesca, Asociación de Amigos del Castillo de Montearagón.

Bassegoda Nonell, Juan (1973), La Catedral de Barcelona: su restauración 1968-1972, Barcelona, Editores Técnicos Asociados.

Bassegoda Nonell, Juan (1984), El sepulcro de Santa Eulalia de Barcelona. Estudio histórico y técnico de su restauración, "Boletín de la Real Academia de Bellas Artes de San Fernando" 58, pp. 122-158.

Beltrán, Antonio; Lacarra, José María; Canellas, Ángel (1976), Historia de Zaragoza, vol. I, Zaragoza, Ayuntamiento de Zaragoza.

Bensch, Stephen (1995), Barcelona and its rulers, 1096-1291, Cambridge, Cambridge University Press.

Bertrand, Gilles; Taddei, Ilaria (2008) Le destin des rituels. Faire corps dans l'espace urbain, Italie-France-Allemagne, Roma, École française de Rome.

Boesch Gajano, Sofia; Michetti, Raimondo (coord.) (2002), Europa Sacra: Raccolte agiografiche e identità politiche in Europa fra Medioevo ed Età moderna, Roma, Carocci.

Boucheron, Patrick; Chiffoleau, Jacques (dir.) (2000), Religion et société urbaine au Moyen Âge: études offertes à Jean-Louis Biget par ses anciens élèves, París, Publications de la Sorbonne.

Brown, Andrew (2011), Civic Ceremony and Religion in Medieval Bruges c. 1300-1520, Cambridge, Cambridge University Press. 
Cabestany i Fort, Joan-Francesc (1996), El culte de Santa Eulàlia a la catedral de Barcelona (s. IX-X), "Lambard. Estudis d'Art Medieval" 9, pp. 159-165.

Campo Gutiérrez, Ana del (2003), Aproximación a un mapa devocional de Zaragoza en el siglo XV, "Turiaso" 16, pp. 87-114.

Cannon, Joann; Wiliamson, Beth (ed.) (2000), Art, Politics and Civic Religion in Central Italy, 1261-1352. Essays by Postgraduate Students at the Courtauld Institute of Art, Nueva York, Ashgate.

Carrillo, Martín (1617), Historia del glorioso san Valero obispo de la ciudad de Çaragoça. Con los martyrios de san Vicente, santa Engracia, san Lamberto y los innumerables martyres, naturales, patrones y protectores de la ciudad de Çaragoça, Zaragoza, [s.n.].

Crouzet-Pavan, Elisabeth (dir.) (2003), Pouvoir et édilité. Les grands chantiers dans l'Italie communale et seigneuriale, Roma, École française de Rome.

Durán Gudiol, Antonio (1985), Historia de los obispos de Huesca-Jaca de 1252-1328, Huesca, Instituto de Estudios Altoaragoneses.

Durán Gudiol, Antonio (1991), Historia de la Catedral de Huesca, Huesca, Instituto de Estudios Altoaragoneses.

Estal Gutiérrez, Juan Manuel del (2009), Itinerario de Jaime II de Aragón (1291-1327), Zaragoza, Institución Fernando el Católico.

Español Bertran, Francesca (2001), Els escenaris del rei: art i monarquia a la Corona d'Aragó, Manresa, Angle.

Fàbrega i Grau, Àngel (1953), Pasionario Hispánico (siglos VII-XI). Tomo I, Madrid, Instituto Enrique Flórez.

Falcón Pérez, María Isabel (1997), Ordenanzas y otros documentos complementarios relativos a las Corporaciones de oficio en el reino de Aragón en la Edad Media, Zaragoza, Institución Fernando el Católico.

Fernández Conde, Francisco Javier (2005), La religiosidad medieval en España. Plena Edad Media (siglos XI-XIII), Gijón, Trea.

Ferrer i Mallol, Maria Teresa (1987), Els sarraïns de la Corona catalanoaragonesa en el segle XIV: segregació i discriminació, Barcelona, Institución Milà i Fontanals, CSIC.

Fontana Calvo, M. ${ }^{a}$ Celia (2008), Sobre la creencia, a comienzos del siglo XVII, del nacimiento de san Lorenzo en la ciudad de Huesca, "Argensola" 118, pp. 223-234.

Garcés Manau, Carlos (2008), Huesca y su patrón san Lorenzo: historia de las tradiciones laurentinas oscenses (siglos XII a XV), "Argensola" 118, pp. 15-84.

Garcés Manau, Carlos (2014), La mezquita-catedral (siglos XII-XIII) y la construcción de la catedral gótica de Huesca (1273-1313): una nueva historia, "Argensola" 124, pp. 211-271. 
Garcés Manau, Carlos (2015), Huesca y su patrón san Lorenzo: nuevas evidencias sobre el origen de las tradiciones laurentinas oscenes, "Argensola" 125, pp. 201-212.

García de Cortázar y Ruiz de Aguirre, José Ángel (2006), La Civitas Dei: la ciudad como centro de vida religiosa en el siglo XIII, en González Jiménez, Manuel (ed.) El mundo urbano en la Castilla del siglo XIII, vol. 1, Sevilla, Fundación El Monte.

García Arnal, María Jesús (en prensa), Los estatutos de las cofradías de San Lorenzo y San Vicente de Huesca (ss. XIII-XVII), Huesca, Instituto de Estudios Altoaragoneses.

García Villada, Zacarías (1922), La traslación del brazo de Santa Tecla desde Armenia a Tarragona (1319-1323). I. Cartas de Jaime II de Aragón a los Reyes de Armenia, "Estudios Eclesiásticos" 1, pp. 41-50.

Garí de Aguilera, Blanca (2010), La política de lo sagrado en la Barcelona medieval: de la inventio santae Eulaliae a las leyendas mercedarias, "Imago temporis. Medium Aevum" 4, pp. 475-490.

Gil de Zamora, Juan, Legende sanctorum et festivitatum aliarum de quibus Ecclesia sollempnizat, ed. José Carlos Martín Iglesias, Eduardo Otero Pereira, Zamora, IEZ "Florián de Ocampo", 2014.

Golinelli, Paolo (1991), Città e culto dei santi nel medioevo italiano, Bolonia, Cooperativa Libraria Universitaria Editrice Bologona.

González Antón, Luís (1975), Las Uniones aragonesas y las Cortes del Reino (1283-1301), Zaragoza, Escuela de Estudios Medievales.

González Antón, Luís (1977), La revuelta de la nobleza aragonesa contra Jaime I en 1224-1227, en Homenaje a Don José María Lacarra de Miguel en su jubilación del profesorado: estudios medievales, Zaragoza, Anubar, vol. 2, pp.143-163.

Harvey, Margaret (2006), Lay Religious Life in Late Medieval Durham, Woodbridge, Boydell Press.

Hinojosa Montalvo, José (2006), Jaime II y el esplendor de la Corona de Aragón, Donostia, Nerea.

Huesca, Ramón de (1792), Teatro histórico de las iglesias del Reino de Aragón. Tomo V, Estado antiguo de la Santa Iglesia de Huesca (reprod. fasc. 2007), Huesca, Instituto de Estudios Altoaragoneses.

Hurtado, Víctor (2005), Llibre de deutes, trameses i rebudes de Jaume de Mitjavila, Barcelona, Institución Milà i Fontanals - CSIC.

Iradiel, Paulino; Navarro, Germán; Igual, David; Villanueva, Concepción (ed.) (2016), Identidades urbanas Corona de Aragón-Italia. Redes económicas, estructuras institucionales, funciones políticas (siglos $X I V-X V)$, Zaragoza, Universidad de Zaragoza. 
Iranzo Muñío, María Teresa (2004), El concejo de Huesca en la Edad Media. Estructura, funcionamiento y financiación de la organización municipal en la Baja Edad Media, Zaragoza, Universidad de Zaragoza (tesis doctoral), https://zaguan.unizar.es/record/56342?ln=es [consulta: 13/03/2018].

Iranzo Muñío, María Teresa; Laliena Corbera, Carlos (1991), El grupo aristocrático en Huesca en la Baja Edad Media: bases sociales y poder político, en Les sociétés urbaines en France méridionale et en Péninsule Ibérique au Moyen Âge (actes du Colloque de Pau, 21-23 septembre 1988), París, Éditions du Centre national de la recherche scientifique, pp. 183-202.

Jaspert, Nikolas (1996), Stift und Stadt: das Heiliggrabpriorat von Santa Anna und das Regularkanonikerstift Santa Eulàlia del Camp im mittelalterlichen Barcelona (1145-1423), Berlín, Duncker unf Humblot.

Juncosa Bonet, Eduard (2010), La bofetada de santa Tecla al rey Pedro el Ceremonioso: el reflejo legendario de las luchas por el control jurisdiccional de Tarragona, "En la España Medieval" 33, pp. 75-95.

Juncosa Bonet, Eduard (2015), Estructura y dinámicas de poder en el señorío de Tarragona: creación y evolución de un dominio compartido (ca. 1118-1462), Barcelona, Institución Milà i Fontanals - CSIC.

Laliena Corbera, Carlos (1988), Documentos municipales de Huesca, 11001350, Huesca, Ayuntamiento de Huesca.

Laliena Corbera, Carlos (1989), La adhesión de las ciudades a la unión: poder real y conflictividad social en Aragón a fines del XIII, "Aragón en la Edad Media" 8, pp. 388-413.

Laliena Corbera, Carlos (1994), Los regadíos medievales en Huesca. Agua y desarrollo social, siglos XII-XV, en Laliena Corbera, Carlos (coord.), Agua y progreso social. Siete estudios sobre el regadío en Huesca, siglos XII-XX, Huesca, Instituto de Estudios Altoaragoneses, pp. 19-44.

Laliena Corbera, Carlos (2010), Las transformaciones de las elites políticas de las ciudades mediterráneas hacia 1300. Cambios internos y movilidad social, en Carocci, Sandro (ed.), La mobilità sociale nel Medioevo, Roma, École française de Rome, pp. 147-185.

Mainé Burguete, Enrique (1999), Infanzones contra ciudadanos. Luchas por el poder en la parroquia de la Magdalena (Zaragoza), "Aragón en la Edad Media" 14, pp. 941-954.

Marinković, Ana; Vedriš, Trpimir (2010), Identity and Alterity in Hagiography and the Cult of Saints, Zagreb, Hagiotheca. 
Martín Iglesias, José Carlos, (2006), Las composiciones en honor de san Braulio y de la basílica del Pilar del códice Paris, BNF, lat. 2277: autoría, datación y finalidad, en Alberto, Aires; Farmhouse, Paulo (coord.), IV Congresso Internacional de Latim Medieval Hispânico, Lisboa, 12-15 de outubro de 2005, Lisboa, Centro de Estudos Clássicos, pp. 639-649.

Montaner Zueras, María José; Laplana Sánchez, José-Ramón (2016), Documentos del Archivo de la Catedral de Huesca 1214-1252, Huesca, Instituto de Estudios Altoaragoneses.

Morte García, Carmen (dir.) (1994), Signos: Arte y Cultura en Huesca. De Forment a Lastanosa. Siglos XVI-XVII, Huesca, Diputación Provincial de Huesca, Gobierno de Aragón.

Muir, Edward (1986), Civic Ritual in Renaissance Venice, Princeton (New Jersey), Princeton University Press.

Narbona Vizcaíno, Rafael (1994), El nueve de octubre. Reseña histórica de una fiesta valenciana: siglos XIV-XX, "Revista d'història medieval" 5, pp. 231-290.

Narbona Vizcaíno, Rafael (1996), Héroes, tumbas y santos. La conquista de las devociones de Valencia medieval, "Saitabi: revista de la Facultad de Geografia i Història" 46, pp. 293-320.

Narbona Vizcaíno, Rafael (2003), Ideología y representación cívica en la sociedad hispánica medieval, en Claramunt Rodríguez, Salvador (coord.), El món urbà a la Corona d'Aragó del 1137 als Decrets de Nova Planta. XVII Congrés d'Història de la Corona d'Aragó, Barcelona - Lleida, 2000, Barcelona, Universidad de Barcelona, vol. 2, pp. 273-288.

Narbona Vizcaíno, Rafael (2004), Cortejos ceremoniales, funciones religiosas y simbolismos políticos en las ciudades medievales, en Barrio Barrio, Juan Antonio (coord.) Los cimientos del Estado en la Edad Media: cancillerías, notariado y privilegios reales en la construcción del Estado en la Edad Media, Alcoy, Marfil, pp. 233-248

Ordinacions $i$ crides de la ciutat de Tarragona (segles XIV-XVII), Tarragona, Ajuntament de Tarragona, 1982.

Pérez Galán, Cristina (2015), Cristianas, judías y musulmanas en la ciudad de Huesca a finales de la Edad Media, Zaragoza, Universidad de Zaragoza (tesis doctoral inédita).

Pérez Martínez, Meritxell (2005-2006), La invenció (inventio) del culte a Santa Tecla en la Tarragona d'època medieval, "Boletín de la Real Academia de Buenas Letras de Barcelona" 50, pp. 21-58.

Pérez-Embid Wamba, Javier (2002), Hagiología y sociedad en la España medieval: Castilla y León (siglos XI-XIII), Huelva, Universidad de Huelva. 
Riera i Melis, Antoni (2005), Els orígens de la manufactura tèxtil a la Corona catalanoaragonesa (c. 1150-1298), en Narbona Vizcaíno, Rafael (coord.), La Mediterrània de la Corona d'Aragó, segles XIII-XVI \& VII Centenari de la Sentència Arbitral de Torrellas, 1304-2004. XVIII Congrés d'Història de la Corona d'Aragó, València 2004, 9-14 setembre, Valencia, Universidad de Valencia, vol. I, pp. 821-902.

Ramón Solans, Francisco Javier (2014), La Virgen del Pilar dice...: usos políticos y nacionales del culto mariano en la España contemporánea, Zaragoza, Universidad de Zaragoza.

Rigon, Antonio (1995), S. Antonio da Pater Padue $a$ Patronus civitatis, en La religion civique à l'époque médiévale et moderne (Chrétienté et Islam): actes du colloque organisé par le Centre de recherche "Histoire sociale et culturelle de l'Occident. XII ${ }^{e}$-XVIII ${ }^{e}$ siècle" de l'Université de Paris X-Nanterre et l'Institut universitaire de France (Nanterre, 21-23 juin 1993), Roma, École française de Rome, pp. 65-76.

Sabaté, Flocel (coord.) (2014a), Identities on the Move, Berna, Peter Lang.

Sabaté, Flocel (coord.) (2014b), Hybrid Identities, Berna, Peter Lang.

Sabaté, Flocel (coord.) (2015a), Perverse Identities. Identities in conflict, Berna, Peter Lang.

Sabaté, Flocel (coord.) (2015b), Conditioned Identities. Wished-for and Unwished-for Identities, Berna, Peter Lang.

San Vicente, Ángel; Canellas López, Ángel (1971), Aragon Roman, Yonne, Zodiaque.

Sánchez Martínez, Manuel (1995), El naixement de la fiscalitat d'estat a Catalunya (segles XII-XIV), Vic, Eumo.

Sanmartí Roset, Montserrtat; Companys i Farrerons, Isabel (eds.) (2011), Actes municipals de Tarragona: 1400-1401, 1401-1402, Tarragona, Arxiu Històric de la Ciutat de Tarragona.

Sanmartí Roset, Montserrat; Rius Jové, Jordi (ed.) (1995), Actes Municipals: ordinacions de la mesa del vi de la ciutat de Tarragona 1382-1424. Actes Municipals 1396, Tarragona, Ajuntament de Tarragona.

Serrano Martín, Eliseo (2014), El Pilar, la historia y la tradición: la obra erudita de Luis Díez de Aux (1562-ca. 1630), Zaragoza, Mira.

Sesma Muñoz, José Ángel (2012), Actividad comercial y ferias mercantiles en Huesca (siglos XIII-XV), en Laliena Corbera, Carlos; Lafuente Gómez, Mario (coord.) Una economía integrada. Comercio, instituciones y mercados en Aragón, 1300-1500, Zaragoza, Universidad de Zaragoza, pp. 265-290.

Sesma Muñoz, José Ángel; Laliena Corbera, Carlos (coord.) (2009), Crecimiento económico y formación de los mercados en Aragón en la 
Edad Media (1200-1350), Zaragoza, Gobierno de Aragón - Grupo CEMA.

Sollerio, Joanne; Pinio, Joanne; Cupero, Guilielmo; Boschio, Petro (1867), Acta Sanctorum Augusti... Tomus Secundus quo dies V, VI, VII, VIII, $I X, X, X I, X I I$, continentur, París, V. Palmé.

Tanzini, Lorenzo (2016), De origine civitatis. The Building of Civic Identity in Italian Communal Chronicles (12 $2^{\text {th }}-14^{\text {th }}$ Century), "Imago temporis: Medium Aevum" 10, pp. 171-189.

Terpstra, Nicholas (1995), Lay Confraternities and Civic Religion in Renaissance Bologna, Cambridge, Cambridge University Press.

Tesauro, Pompilio (ed.) (1992), Martirio de san Lorenzo, en Uría, Isabel (coord.), Gonzalo de Berceo. Obra completa, Madrid, Espasa-Calpe.

Tomás Ávila, Andrés (1963), El culto y la liturgia en la Catedral de Tarragona (1300-1700), Tarragona, Diputación Provincial de Tarragona.

Utrilla Utrilla, Juan Fernando (1977), El monedaje de Huesca de 1284 (Contribución al estudio de la ciudad y de sus habitantes), “Aragón en la Edad Media" 1, pp. 1-50.

Utrilla Utrilla, Juan Fernando (1995), Los orígenes de la industria textil en Huesca: la construcción de los primeros molinos traperos (c. 1180-1190) y la creación de la cofradía de los tejedores oscense (1239), en Homenaje a don Antonio Durán Gudiol, Huesca, Instituto de Estudios Altoaragoneses, pp. 805-816.

Vauchez, André (1986), Patronage des saints et religion civique dans l'Italie communale à la fin du Moyen Âge, en Moleta, Vicent (ed.) Patronage and Public in the Trecento, St. Lambrecht Symposium, Abtei St. Lambrecht, Styria, 16-19 July, 1984, Florencia, Leo S. Olschki.

Vauchez, André (1987), Les laïcs au Moyen Age: pratiques et expériences religieuses, París, Cerf.

Vauchez, André (1995), La religion civique à l'époque médiévale et moderne (Chrétienté et Islam): actes du colloque organisé par le Centre de recherche "Histoire sociale et culturelle de l'Occident. XII ${ }^{e}$-XVIII ${ }^{e}$ siècle" de l'Université de Paris X-Nanterre et l'Institut universitaire de France (Nanterre, 21-23 juin 1993), Roma, École française de Rome.

Ventrone, Paola (2012), La construzione dell'identità cittadina in Italia tra XIII e XV secolo: feste, rituali, simboli, en Sabaté, Flocel (ed.) Identitats (Aurembiaix d'Urgell), Lleida, Pagès.

Vorágine, Jacobo de (1982), La leyenda dorada, trad. Macías, José Manuel, Madrid, Alianza.

Fecha de recepción del artículo: octubre 2018

Fecha de aceptación y versión final: marzo 2018 